Contents available at: Sri Lanka Journals Online

\title{
Comparative Analysis of Antioxidant and Antimicrobial Properties of Banana and Lime Fruit Peel Extracts
}

\author{
D.M.C.P Daundasekara ${ }^{1 *}$ and R.P.N.P Rajapaksha ${ }^{2}$ \\ ${ }^{1}$ Postgraduate Institute of Agriculture, University of Peradeniya, Peradeniya, Sri Lanka. \\ 2 Department of Food Science and Technology, Faculty of Agriculture, University of Peradeniya, Peradeniya, Sri Lanka.
}

\section{ARTICLE INFO}

\section{Article history:}

Received: 11 August 2020

Revised version received: 13 October 2020

Accepted: 18 January 2021

Available online: 1 April 2021

\section{Keywords:}

Antimicrobial activity

Antioxidant activity

Peel extract

Phenolic content

Technological change

\section{Citation:}

Daundasekara, D.M.C.P. and Rajapaksha, R.P.N.P (2021). Comparative Analysis of Antioxidant and Antimicrobial Properties of Banana and Lime Fruit Peel Extracts. Tropical Agricultural Research, 32(2): 146-154:

DOI: http://doi.org/10.4038/tar.v32i2.8462

Daundasekara D.M.C.P

https://orcid.org/0000-0002-8447-3045

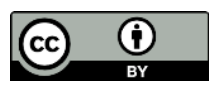

\section{ABSTRACT}

Fruit peels generated during food processing are generally considered as waste and are not further utilized. However, studies conducted on fruit peels have revealed the presence of constituents that could be used for pharmacological or pharmaceutical applications. To evaluate the potential of extracting such health promoting bioactive materials from fruit peels, current study was aimed to determine the polyphenolic content and the antioxidative and antimicrobial activities of methanolic peel extracts of four local banana (Musa sapientum) varieties (Ambul, Anamalu, Seeni and Kolikuttu) and lime (Citrus aurantifolia).The Folin-Ciocalteu method was employed to calculate the total phenolic content, and antioxidant capacity was assessed with DPPH, ABTS + and TBARS assays. The antimicrobial efficacy was determined using agar well diffusion method against Staphylococcus aureus and Escherichia coli. According to the results, lime and Anamalu banana peel exhibited the highest total phenolic content $(178.30 \pm 2.46 \mu \mathrm{g}$ $\mathrm{GAE} / \mathrm{ml}, 120.27 \pm 0.89 \mu \mathrm{g} \mathrm{AAE} / \mathrm{ml}$ and $177.87 \pm 3.68 \mu \mathrm{g} \mathrm{GAE} / \mathrm{ml}$, $102.11 \pm 1.35 \mu \mathrm{g} A \mathrm{AE} / \mathrm{ml}$ respectively). All fruit peel extracts showed high scavenging effects on DPPH and ABTS+ radicals with IC50 values ranging from $51.51 \% \pm 0.76$ to $54.65 \% \pm 0.11$ and $51.56 \% \pm 0.35$ to $67.14 \% \pm 1.38$ respectively. Lime and Ambul banana showed the lowest total TBARS content. All tested banana peel extracts showed no antimicrobial activity while the absolute lime peel extracts showed a high zone of inhibition $(1.9 \pm 0.0 \mathrm{~cm})$ against E. coli and $(1.8 \pm 0.1 \mathrm{~cm}) S$. aureus. Current study provides the initial evidence of having antioxidant and antimicrobial properties in banana and lime peel. Thus, a potential exists to extract the bioactive materials responsible for such properties focusing possible applications.

*Corresponding author: chathuminidaundasekara@gamil.com 


\section{INTRODUCTION}

Fruits are considered as an important part of a healthy and balanced diet. Fruit waste and byproducts are formed in great amounts during industrial processing of fruits. These have usually been discarded creating a serious problem on environment. Therefore, it is important to find effective ways to manage or utilize waste materials and by-products formed during fruit processing (Sagar et al., 2018). Extensive researches on utilizing these wastes are being carried out worldwide (Gowe, 2015).

Previous researches have proved the antimicrobial activity of selective varieties of lime and banana peel extracts against some bacterial strains (Mahmud et al., 2009; Aboul-Enein et al., 2016). The peel of citrus fruits is a rich source of flavanones and polymethoxylated flavones that rarely occur in other plants (Nogata et al., 2006). The major components of lime peel essential oil proved to be $\beta$-pinene (12.6\%), limonene $(53.8 \%)$, $\gamma$-terpinene $(16.5 \%)$, terpinolene $(0.6 \%), \alpha$ terpineol $(0.4 \%)$ and citral (2.5\%) (Dosoky and Setzer, 2018). These are most likely to be associated with the good antimicrobial activity, in particular on gram-positive bacteria such as Staphylococcus aureus, Bacillus subtilis and Staphylococcus epidermidis. The lime peel demonstrated a strongest radical scavenging activity. The most abundant flavonoids found in C. aurantifolia extracts were apigenin, rutin, quercetin, kaempferol and nobiletin (Tundis et al., 2012).

Banana peel is a rich source of phenolic compounds (Tsamo et al., 2015). The total amount of phenolic compounds in banana peel has been reported as 0.90 to $3.0 \mathrm{~g} / 100 \mathrm{~g}$ dry weight. The flavonoids detected in banana peel are as quercetin, myricetin, kaempferol, and cyaniding. These provide health benefits mainly by acting as free radicals including reactive oxygen species (ROS), and reactive nitrogen species (RNS) (Kevers et al., 2007). In bananas the peel can be the major source of obtaining natural antioxidant. Ascorbic acid, tocopherol, beta carotene, phenolic groups, dopamine and gallocathechin are antioxidant compounds identified in banana peel. Anthocyanins, delphinidin, cyaniding and catecholamines also contain in ripe banana peel. In addition, carotenoids such as $\alpha$-carotene, $\beta$ carotene and xanthophylls have been discovered in banana peel as well as sterols and triterpenes (Ayala-Zavala et al., 2011). Researchers have demonstrated the antimicrobial activity of banana peel against various gram-positive and gramnegative bacteria including $M$. catarrhalis, $S$. aureus, S. pyogenes, E. aerogenes and K. pneumonia (Chabuck et al., 2013).

The effects of antioxidants in banana and lime peel extracts in scavenging the free radicals have been reported in previous studies (GonzálezMontelongo et al., 2010; Bocco et al., 1998). In this study, methanolic extracts of peels from four common varieties of banana; Ambul Banana (Sour banana or Musa acuminata, AA), Seeni Banana (Sweet banana or Musa acuminata $\times$ Musa balbisiana, AABB), Anamalu Banana (Gros Michel or Musa acuminata, AAA), Kolikuttu Banana (Latundan or Musa acuminata $\times$ Musa balbisiana, $\mathrm{AAB}$ group) and lime, , those are commonly consumed in Sri Lanka were obtained and tested for the antioxidant and antimicrobial properties. The results of this study will aid in developing new effective antimicrobial agents as well as natural antioxidant agents with potential applications in food and pharmaceutical industries.

\section{METHODOLOGY}

\section{Collection of plant samples}

Healthy plants of lime and four varieties of banana (Ambul Banana (Musa acuminata, AA), Anamalu Banana (Musa acuminata, AAA), Kolikuttu Banana (Musa acuminata $\times$ Musa balbisiana, AAB), Seeni Banana (Musa acuminata $\times$ Musa balbisiana, AABB) were purchased from retail vendors, and brought into the laboratory under humid conditions.

\section{Pre-treatment and surface sterilization of samples}

Fruits were washed with tap water and then with distilled water. Fruit peels were removed and shade dried at room temperature $\left(30-32^{\circ} \mathrm{C}\right)$ for three days. The dried peels were grounded and kept in an air tight polyethylene bag until extraction.

\section{Crude extraction}

Pulverized peel (25 g) of each sample was soaked separately in $500 \mathrm{ml}$ of methanol (99\%) and kept in a shaker for 3 days. Each preparation was filtered through a sterilized Whatman No.1 filter paper and the filtered extract was concentrated to $25 \mathrm{ml}$ solutions using a rotary evaporator $30 \mathrm{rpm}$, $\left.40^{\circ} \mathrm{C}\right)$. The extract was stored in the refrigerator $(4$ $\left.{ }^{\circ} \mathrm{C}\right)$.

\section{Determination of total phenolic content}

The total phenolic content was determined according to the method described by Lordan et al. (2013). Briefly, $10 \mu \mathrm{g}$ standard or the extract was mixed with $50 \mu \mathrm{l}$ Folinciocalteu's reagent in 96 well 
microplate and then it was incubated at room temperature for $5 \mathrm{~min}$. Sodium carbonate $(40 \mu \mathrm{l}$ of $7.5 \%$ ) was added to the reaction mixture and incubated in the dark for $2 \mathrm{~h}$ and the absorbance was measured using a microplate reader (Thermo Scientific Multiskan Go, Thermo Fisher Scientific, USA) at $750 \mathrm{~nm}$. Gallic acid and ascorbic acid were used as the standards in the concentration range of $25 \mu \mathrm{g} / \mathrm{ml}-450 \mu \mathrm{g} / \mathrm{ml}$. Results were expressed as $\mu \mathrm{g}$ Gallic acid/ $\mathrm{ml}$ and $\mu \mathrm{g}$ Ascorbic acid/ $\mathrm{ml}$ of extract.

\section{Determination of antioxidant activity \\ DPPH radical scavenging activity:}

DPPH radical scavenging activity was determined according to the method described by Farasat and Khavari-nejad, 2014. Each extract $(100 \mu \mathrm{l})$ of 25,50 and $100 \%$ was separately mixed with $100 \mu$ Llof $0.16 \mathrm{mM}$ DPPH solution and vortexed for $1 \mathrm{~min}$. After incubating at dark for 30 min the absorbance was measured at $517 \mathrm{~nm}$ using microplate reader. Gallic acid and ascorbic acid were used as the standards. Percentage inhibition was calculated according to the equation (1).

Inhibition $(\%)=\left(1-\frac{(\text { A sample-A blank })}{\text { A control }} \times 100 \ldots .(1)\right.$

where, A control is DPPH without sample, A sample is sample + DPPH, and A blank is sample without DPPH.

\section{ABTS ++ radical scavenging activity:}

ABTS + radical scavenging activity was determined according to the method Rajurkar and Hande, 2011. ABTS-+radical was generated by reacting 7 mM ABTS in water and $2.45 \mathrm{mM}$ potassium persulfate (1:1), stored in the dark at room temperature for 12-16 $\mathrm{h}$ before use. ABTS-+solution was then diluted with methanol to obtain an absorbance of 0.70 at $734 \mathrm{~nm}$. After the addition of $5 \mu$ l of dilutions 25, 50 and $100 \%$ to $3.995 \mathrm{ml}$ of diluted ABTS-+ solution, the absorbance was measured $30 \mathrm{~min}$ after the initial mixing, at $517 \mathrm{~nm}$ using a microplate reader. Gallic acid was used as the standard. Percentage inhibition was calculated according to the equation (2).

Inhibition $(\%)=(1-($ B sample - B blank $)) \times 100 \ldots .(2)$

$$
\text { B control }
$$

where, B control is ABTS-+ without sample, B sample is sample + ABTS $\cdot+$, and B blank is sample without ABTS.+

\section{TBARS (lipid peroxidation) assay:}

TBARS was determined according to the method described by Chen et al., 2017. Each sample (2 g) was weighted into a centrifuge tube and $5 \mathrm{ml}$ of $10 \%(\mathrm{w} / \mathrm{v})$ TCA was added. It was vortexed at high speed for 2 min and the aqueous solution of 2tiobarbituric acid $(0.02 \mathrm{M}, 5 \mathrm{ml})$ was added and vortexed for $30 \mathrm{sec}$. Solution was centrifuged at $3000 \mathrm{xg}$ for $10 \mathrm{~min}$ and the supernatant was filtered through a Whatman No 03 filter paper. Filtrate was placed in a boiling water bath for 45 min and was cooled to room temperature on ice. The absorbance was measured at $532 \mathrm{~nm}$, and the total TBARS content was calculated according to the following equation.

\section{Total TBARS $=$ Absorption $532 \mathrm{~nm} \times 7$}

\section{Agar well diffusion antimicrobial assay:}

Pathogenic strains of Staphylococcus aureus (ATCC 25923) and Escherichia coli (ATCC 35217)were obtained from American Type Cell Culture Collection, UAS and a loopful of the test isolates were taken from a stored agar slant and swabbed uniformly on Muller hunter agar (MHA) petri dishes separately and incubated at $37^{\circ} \mathrm{C}$ for $24 \mathrm{~h}$. A loopful of the active colonies obtained were taken with a sterile wire loop, transferred into a $5 \mathrm{~mL}$ of sterile saline $(0.85 \%)$. Turbidity of the inoculums' were be compared with 0.5 McFarland standard solution (containing approximately $1.5 \times 108$ $\mathrm{CFU} / \mathrm{ml}$ ) as explained by Stefanovic and Comic, 2012.

Antimicrobial screening was performed using the agar well diffusion method. The MHA media was punched with $7 \mathrm{~mm}$ diameter wells and filled with each extract $(50 \mu \mathrm{l})$ at different concentrations $(25$, $35,50$ and $100 \%)$. The plates were then incubated at $37^{\circ} \mathrm{C}$ for $24 \mathrm{~h}$. After the incubation, the zone of microbial growth inhibition due to each extract was measured in cm (Obinna et al., 2008). Same procedure was continued, and the wells were filled with absolute extracts with different volumes (50, $100,200,300 \mu \mathrm{l})$. The antibiotic, Ofloxacin was used as the positive control and methanol was used as the negative controller.

\section{Statistical analysis}

All statistical analyses were conducted using Minitab 16 software. The inhibition zones were calculated as mean \pm SD. The significance among different data was evaluated by analysis of variance (One Way ANOVA) using general linear model with 95\% confident level. 


\section{RESULTS AND DISCUSSION}

\section{Total phenolic content}

Total phenol compounds are reported as gallic acid and ascorbic acid equivalents by reference to standard curve $(\mathrm{y}=0.0023 \mathrm{x}+0.2899, \mathrm{R} 2=0.971)$ and $(\mathrm{y}=0.0063 \mathrm{x}+0.0557, \mathrm{R} 2=0.99)$ respectively.

There were statistically significant differences $(\mathrm{p}<0.05)$ in TPC among different peel extracts suggesting that TPC is dependent on the type of peel extract (Table 1).The methanolic extract of lime peel exhibited a higher TPC $(178.30 \pm 2.46 \mu \mathrm{g}$ $\mathrm{GAE} / \mathrm{ml}$ and $120.27 \pm 0.89 \mu \mathrm{g} \mathrm{AAE} / \mathrm{ml}$ ) compared to the banana peel extracts. Among the banana varieties, Anamalu banana peel had the highest total phenol content $(177.87 \pm 3.68 \mu \mathrm{g} \mathrm{GAE} / \mathrm{ml}$ and $102.11 \pm 1.35 \mu \mathrm{g} \mathrm{AAE} / \mathrm{ml}$ ) and Seeni banana peel had the lowest total phenol content $(-6.48 \pm 1.84 \mu \mathrm{g}$ $\mathrm{GAE} / \mathrm{ml}, 34.80 \pm 0.67 \mu \mathrm{g}$ AAE$/ \mathrm{ml})$. Higher phenolic content in the methanolic extract is responsible for the bioactivity, thus, lime peel extract and Anamalu peel extract are expected to exhibit better antioxidant and antibacterial activities.

Table 1: Mean $( \pm S D)$ total phenolic content of peel extracts

\begin{tabular}{lrr}
\hline Sample & \multicolumn{2}{c}{ Total Phenolic Content } \\
\cline { 2 - 3 } & $\begin{array}{r}\text { Gallic Acid } \\
\text { ( } \boldsymbol{\mu g} \text { GAE/ml } \\
\text { extract) }\end{array}$ & $\begin{array}{r}\text { Ascorbic Acid } \\
\text { ( } \boldsymbol{\mu g} \text { AAE/ml } \\
\text { extract) }\end{array}$ \\
\hline Ambul & $113.52 \pm 9.22$ & $78.62 \pm 3.37$ \\
Anamalu & $177.87 \pm 3.68$ & $102.11 \pm 1.35$ \\
Kolikuttu & $52.00 \pm 2.16$ & $56.15 \pm 0.78$ \\
Seeni & $-6.48 \pm 1.84$ & $34.80 \pm 0.67$ \\
Lime & $178.30 \pm 2.46$ & $102.27 \pm 0.89$ \\
\hline
\end{tabular}

note $\mathrm{GAE}=$ gallic acid equivalents, $\mathrm{AAE}=$ ascorbic acid equivalents

Similar to current findings previous researches have also revealed a higher tpc of banana and lime peel extracts (gonzalez-montelongo et al., 2010; singanusong et al., 2015; aboul-enein et al., 2016; fatemeh et al., 2012). Specifically, singanusong et al., 2015 revealed tpc of lime peel as $987.51 \mathrm{mg}$ gae/100 g. Aboul-enein et al., 2016 showed that tpc in methanolic extract of banana peels as 17.89 , $\mathrm{mg} / \mathrm{g} \mathrm{dw}$. Further, fatemeh et al., 2012 reported the tpc in two varieties of banana peel (cavendish and dream) as 585.29 and $685.57 \mathrm{mg}$ gae/100 g dry matter and 91.90 and $160.77 \mathrm{mg}$ gae/100 g dry matter at two stages of ripeness (ripe and green). Different extract concentrations and different procedures adopted for tpc analysis, even when using gallic acid as reference are likely to give different results. Therefore, we were unable to conduct direct comparison of these findings with current study results due to differences in assessment methods and fruit varieties used.

\section{DPPH radical scavenging activity}

Concentration (\%) of the antioxidants present in a (peel extract) required for the inhibition of DPPH radical up to $50 \%$, was calculated as IC50, by linear regression analysis using a graph constructed by plotting the percentage of scavenging against the respective concentration of standard antioxidants (Ambul; $\mathrm{y}=91.659 \mathrm{x}+0.7159, \quad \mathrm{R} 2=0.9997$, Anamalu; $\mathrm{y}=97.695 \mathrm{x}-0.66, \mathrm{R} 2=0.9997$, Kolikuttu; $\mathrm{y}=91.371 \mathrm{x}+0.4075, \mathrm{R} 2=0.9998$, Seeni; $\mathrm{y}=91.564 \mathrm{x}$ $-0.0501, R 2=0.9998$ and lime; $y=98.343 x-0.658$, $\mathrm{R} 2=0.9999$ ).

Both, banana and lime extracts, of the present work showed free radical (DPPH) scavenging or antioxidant activity in a concentration-dependent manner. The lime peel extract had higher value (51.51\% \pm 0.76$)$ compared to that of all banana types (Table 2). The banana variety Seeni showed the lowest antioxidant activity $(54.65 \% \pm 0.11)$.

Table 2: Mean $( \pm \mathrm{SD})$ DPPH radical scavenging activity of peel extracts

\begin{tabular}{lr}
\hline Sample & $\begin{array}{r}\text { DPPH Radical Scavenging } \\
\text { Activity\% (IC } 5 \text { ) }\end{array}$ \\
\hline Ambul & $53.77 \pm 1.53$ \\
Anamalu & $51.85 \pm 0.63$ \\
Kolikuttu & $54.26 \pm 0.86$ \\
Seeni & $54.65 \pm 0.11$ \\
Lime & $51.51 \pm 0.76$ \\
Gallic Acid & $14.87 \pm 1.31$ \\
Ascorbic acid & $15.45 \pm 0.59$ \\
\hline
\end{tabular}

According to Loizzo et al., 2012 the methanolic extract of lime peels extracted from 3 different areas in of high Jonio coast in Cosenza province, Italy, showed DPPH IC50 values between 78.3 and $93.8 \mathrm{gmL}^{-1}$. Aboul-Eneinet et al., (2016) have reported that DPPH IC50 values of banana peel depends on the type of extract used. According to them banana peel extract with $80 \%$ methanol was $56.22 \mu \mathrm{gmL}^{-1}, 80 \%$ ethanol was $75.34 \mu \mathrm{gmL}^{-1}$, aqueous extract was $120.03 \mu \mathrm{gmL}^{-1}$, and $80 \%$ acetone was $55.45 \mu \mathrm{gmL}^{-1}$.

\section{ABTS-+radical scavenging activity}

The concentration (\%) of these compounds required to inhibit $50 \%$ of the radical-scavenging effect $\left(\mathrm{IC}_{50}\right)$ was determined by linear regression analysis using a graph constructed by plotting the percentage of scavenging against the respective concentration of standard antioxidants (Ambul; $y=$ 
$80.654 \mathrm{x}+3.7119, \mathrm{R}^{2}=1$, Anamalu; $\mathrm{y}=83.317 \mathrm{x}+$ $1.0702, \mathrm{R}^{2}=1$, Kolikuttu; $\mathrm{y}=82.83+1.8833, \mathrm{R}^{2}=$ 0.9996 , Seeni; $\mathrm{y}=76.503 \mathrm{x}-1.3467, \mathrm{R}^{2}=0.9986$ and lime; $\left.y=98.848 \mathrm{x}-0.9795, \mathrm{R}^{2}=0.9996\right)$. The radical scavenging activity of banana peel and lime peel extracts were compared with those of gallic acid and ascorbic acid at the same concentrations. The lower $\mathrm{IC}_{50}$ value reflects greater antioxidant activity of the sample. The results of ABTS-+scavenging activity of banana peel extracts and lime peel extracts are summarized in Table 3 (IC 50 values)

Table 3: Mean ( \pm SD) $\mathrm{ABTS}^{+}$radical scavenging activity of peel extracts

\begin{tabular}{lr}
\hline Sample & $\begin{array}{r}\text { ABTS }^{+} \text {Radical Scavenging } \\
\text { Activity\% (IC) }\end{array}$ \\
\hline Ambul & $7.39 \pm 0.80$ \\
Anamalu & $58.72 \pm 0.84$ \\
Kolikuttu & $58.08 \pm 0.47$ \\
Seeni & $67.14 \pm 1.38$ \\
Lime & $51.56 \pm 0.35$ \\
Gallic acid & $13.04 \pm 0.15$ \\
\hline
\end{tabular}

The results from the antioxidant assay showed that tested peel extracts have a potential scavenge free radicals to a certain extent. The highest ABTS-+ radical scavenging activity was reported in lime peel $(51.56 \% \pm 0.35)$ and it could be due to the presence of higher phenolic content. The tested banana peel extracts showed antioxidant activity in the order of Ambul (57.39\% \pm 0.80$)$, Kolikuttu (58.08\% 0.47$)$, Anamalu (58.72\% \pm 0.84 ) and Seeni $(67.14 \% \pm 1.38)$ from highest to the lowest.

Loizzo et al., 2012 have reported that the TEAC values for ABTS assay with methanolic extracts of lime peels from 3 different areas of high Jonio coast in Cosenza province, Italy were between 18.7 and $41.4 \mu \mathrm{M} / \mathrm{g}$ and depend on the area of growth. According to GomesRebello et al., 2014 the ABTS assay TEAC value of banana peel was $242 \mu \mathrm{M} / \mathrm{g}$. However, current results could not be compared with these findings due to the differences in the methods used for assessing the ABTS•+ scavenging activity.

Table 5: Mean inhibition zone values of peel extracts $(50 \mu \mathrm{l})$ against $S$. aureus

\section{TBARS lipid peroxidation activity}

TBARS assay detects the level of malondialdehyde (MDA), the major lipid oxidation product, and also some minor related compounds.

The results illustrate that the total TBARS content is low, and antioxidant activity is high in lime peel extract, followed by Ambul banana, when compared with the standards gallic acid and ascorbic acid. Further it was observed that, though the total TBARS content is high in Seeni banana peel extract its, antioxidant activity is low.

Table 4: Mean ( \pm SD) total TBARS content

\begin{tabular}{lc}
\hline Sample & $\begin{array}{c}\text { Total TBARS } \\
(\boldsymbol{\mu M} / \mathbf{g})\end{array}$ \\
\hline Ambul & 1.84 \\
Anamalu & 4.74 \\
Kolikuttu & 3.06 \\
Seeni & 5.83 \\
Lime & 2.20 \\
Gallic & 1.58 \\
Ascorbic Acid & 1.86 \\
\hline
\end{tabular}

\section{Antimicrobial Activity}

The peel extracts of five plant species were investigated to evaluate their antibacterial activity against S.aureus and E.coli using well diffusion method.Antibacterial activity of the tested peel extracts- (50 ul) against S. aureus and E.coliwere initially evaluated with different concentrations $(25,35,50$, and $100 \%)$ as shown in Table 5 and Table 6 . The results revealed that banana peel extracts and lime peel extract have no potential antimicrobial activity when compared with the antibiotic, the positive controller used for both bacteria. The antibacterial activity of concentrated peel extracts of lime and banana varieties were evaluated against $S$. aureus and $E$.coli with different volumes. The results are summarized in the Tables 7 and 8, and Figures 1 and 2).

\begin{tabular}{lccccccc}
\hline Concentration & \multicolumn{6}{c}{ Mean inhibition zone diameter (cm) \pm SD } \\
\cline { 2 - 7 } & Ambul & Anamalu & Kolikuttu & Seeni & Lime & Antibiotic & Methanol \\
\hline $25 \%$ & $n z i$ & $n z i$ & $n z i$ & $n z i$ & $n z i$ & $1.1 \pm 0.0$ & $n z i$ \\
$35 \%$ & $n z i$ & $n z i$ & $n z i$ & $n z i$ & $n z i$ & $1.1 \pm 0.0$ & $n z i$ \\
$50 \%$ & $n z i$ & $n z i$ & $n z i$ & $n z i$ & $n z i$ & $1.3 \pm 0.0$ & $n z i$ \\
$100 \%$ & $n z i$ & $n z i$ & $n z i$ & $n z i$ & $n z i$ & $1.5 \pm 0.1$ & $n z i$ \\
\hline
\end{tabular}

Note: nzi= no zone of inhibition 


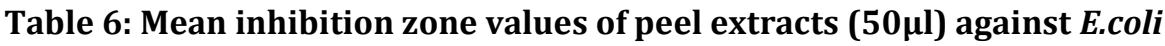

\begin{tabular}{lccccccc}
\hline Concentration & \multicolumn{7}{c}{ Mean inhibition zone diameter (cm) \pm SD } \\
\cline { 2 - 8 } & Ambul & Anamalu & Kolikuttu & Seeni & Lime & Antibiotic & Methanol \\
\hline $25 \%$ & $n z i$ & $n z i$ & $n z i$ & $n z i$ & $n z i$ & $1.7 \pm 0.0$ & $n z i$ \\
$35 \%$ & $n z i$ & $n z i$ & $n z i$ & $n z i$ & $n z i$ & $1.9 \pm 0.0$ & $n z i$ \\
$50 \%$ & $n z i$ & $n z i$ & $n z i$ & $n z i$ & $n z i$ & $2.3 \pm 0.0$ & $n z i$ \\
$100 \%$ & $n z i$ & $n z i$ & $n z i$ & $n z i$ & $n z i$ & $2.6 \pm 0.1$ & $n z i$ \\
\hline
\end{tabular}

Note: nzi= no zone of inhibition

Table 7: Mean inhibition zone values of peel extracts (100\%) at different volumes against S. aureus

\begin{tabular}{lccccccc}
\hline $\begin{array}{l}\text { Volume } \\
(\boldsymbol{\mu} \mathbf{)})\end{array}$ & \multicolumn{7}{c}{ Mean inhibition zone diameter $(\mathbf{c m}) \pm$ SD } \\
\cline { 2 - 7 } & Ambul & Anamalu & Kolikuttu & Seeni & Lime & Antibiotic & Methanol \\
\hline 300 & $n z i$ & $n z i$ & $n z i$ & $n z i$ & $1.8 \pm 0.1$ & $2.6 \pm 0.0$ & $n z i$ \\
200 & $n z i$ & $n z i$ & $n z i$ & $n z i$ & $1.7 \pm 0.0$ & $2.5 \pm 0.0$ & $n z i$ \\
150 & $n z i$ & $n z i$ & $n z i$ & $n z i$ & $1.6 \pm 0.0$ & $2.1 \pm 0.0$ & $n z i$ \\
100 & $n z i$ & $n z i$ & $n z i$ & $n z i$ & $1.5 \pm 0.0$ & $2.1 \pm 0.0$ & $n z i$ \\
50 & $n z i$ & $n z i$ & $n z i$ & $n z i$ & $n z i$ & $1.5 \pm 0.1$ & $n z i$ \\
\hline
\end{tabular}

Note: nzi= no zone of inhibition

Table.8: Mean inhibition zone values of peel extracts (100\%) against $E$.coli

\begin{tabular}{|c|c|c|c|c|c|c|c|}
\hline \multirow{2}{*}{$\begin{array}{l}\text { Volume } \\
\text { (ml) }\end{array}$} & \multicolumn{7}{|c|}{ Mean inhibition zone diameter $(\mathrm{cm}) \pm$ SD } \\
\hline & $\begin{array}{c}A m b \\
u l\end{array}$ & Anamalu & Kolikuttu & Seeni & Lime & Antibiotic & Methanol \\
\hline 300 & $n z i$ & $n z i$ & $n z i$ & $n z i$ & $1.9 \pm 0.0$ & $3.3 \pm 0.2$ & $n z i$ \\
\hline 200 & $n z i$ & $n z i$ & $n z i$ & $n z i$ & $1.1 \pm 0.0$ & $3.1 \pm 0.0$ & $n z i$ \\
\hline 150 & $n z i$ & $n z i$ & $n z i$ & $n z i$ & $1.1 \pm 0.0$ & $3.0 \pm 0.0$ & $n z i$ \\
\hline 100 & $n z i$ & $n z i$ & $n z i$ & $n z i$ & $n z i$ & $3.0 \pm 0.0$ & $n z i$ \\
\hline 50 & $n z i$ & $n z i$ & $n z i$ & $n z i$ & $n z i$ & $2.7 \pm 0.1$ & $n z i$ \\
\hline
\end{tabular}

Note: $n z i=$ no zones of inhibition

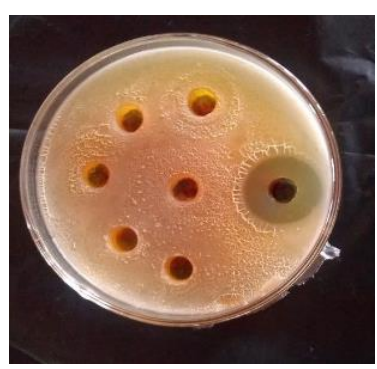

(a)

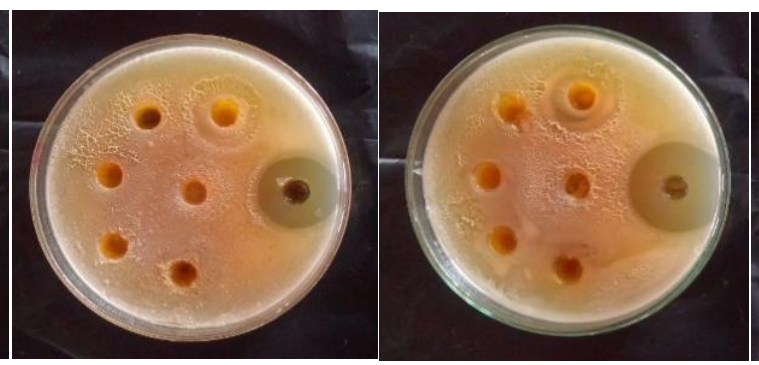

(c)

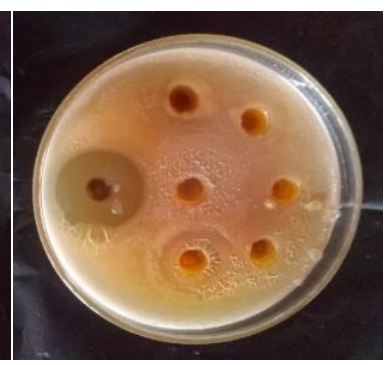

(d)

Figure 1: Mean inhibition zone diameter lime peel extracts (100\%) at different volumes against $S$. aureus (a) $100 \mathrm{ml}$ (b) $150 \mathrm{ml}$ (c) $200 \mathrm{ml}$ (d) $300 \mathrm{ml}$ 


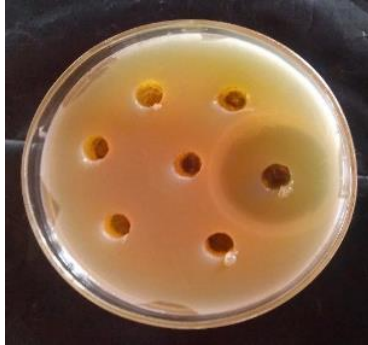

(a)

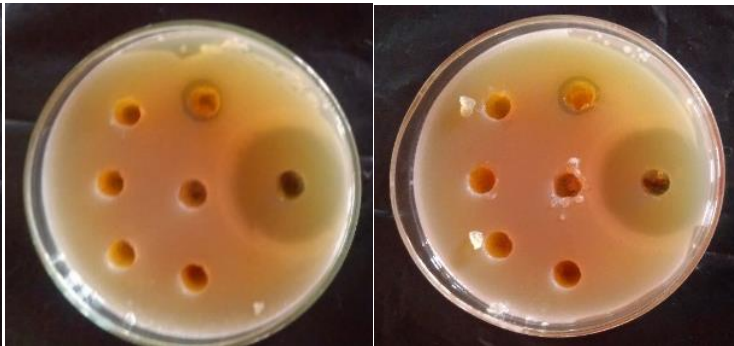

(b) (c)

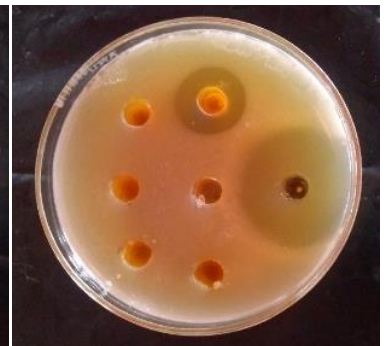

(d)

Figure 2: Mean inhibition zone diameter lime peel extracts $(100 \%)$ at different volumes against $E$. coli (a) $100 \mathrm{ml}$ (b) $150 \mathrm{ml}$ (c) $200 \mathrm{ml}$ (d) $300 \mathrm{ml}$

All the four banana varieties showed negative antimicrobial affect against the selected bacteria. But when compared with the positive control, the lime peel extract noted a significant antimicrobial activity against $S$. aureus and $E$. coli at volumes below $100 \mu \mathrm{l}$ and $150 \mu \mathrm{l}$ respectively. At volume $300 \mu$ lime peel showed the highest antimicrobial activity against the bacteria $E$. coli.

The results from previous studies of Sekar et al., 2013, agreed with the current study indicating that the methanol extract of citrus varieties showed lower to moderate antibacterial activity towards $S$. aureus and E. coli at $20 \mathrm{mg} / \mathrm{ml}$. However, other citrus verities had better inhibition compared to lime. Acheampong et al., 2015, indicated a high antimicrobial capacity of fresh peels of lime compared to the dried peels.

In contrast to the current study findings, have demonstrated a good inhibitory effect of aqueous banana peel extract $(0.1 \mathrm{ml})$ against $S$. aureus with inhibition zone $30 \mathrm{~mm}$. According to Bankar et al., 2010 and Chabuck et al., 2013. E. coli showed no susceptibility to banana peel extract and is in line with the current study findings. Sumathy. 2011, studied the antifungal and antimicrobial properties of yellow banana fruit peel and found that it is effective against different gram positive and negative bacteria. Additionally, Aboul-Enein et al., 2016, showed that $80 \%$ ethanol extract inhibited bacterial species at $400 \mu \mathrm{g} / \mathrm{ml}$ against bacteria $S$. aureus $(10.53 \mathrm{~mm})$ and E. coli $(9.67 \mathrm{~mm})$. The differences in current results in comparison to previous findings could be due to the differences in the banana varieties and methodologies used.

\section{REFERENCES}

Aboul-Enein, A. M., Salama, Z. A., Gaafar, A. A., Aly, H. F., Faten, A., and Ahmed, H. A. (2016). Identification of phenolic compounds from banana peel (Musa paradaisica L.) as

\section{CONCLUSION}

In the current study, the antioxidant and antimicrobial potency of methanolic peel extract of lime and four commonly consumed banana varieties in Sri Lanka were evaluated. The results showed that phenolic content is highest in lime peel extract $(178.30 \pm 2.46 \mu \mathrm{g} \mathrm{GAE} / \mathrm{ml}$ and $120.27 \pm 0.89 \mu \mathrm{g}$ AAE $/ \mathrm{ml}$ ) followed by Anamalu banana variety $(177.87 \pm 3.68 \mu \mathrm{g} \mathrm{GAE} / \mathrm{ml}$, and 102.11 $\pm 1.35 \mu \mathrm{g}$ AAE/ml). While, Seeni banana showed the lowest phenolic content $(-6.48 \pm 1.84 \mu \mathrm{g}$ $\mathrm{GAE} / \mathrm{ml}, 34.80 \pm 0.67 \mu \mathrm{g} \mathrm{AAE} / \mathrm{ml})$. The banana and lime peel extracts possess a good ability to scavenge the free radicals DPPH and ABTS-+. Moreover, Lime and Anamalu banana had the highest DPPH scavenging activity (IC 50 : $51.51 \% \pm 0.76 ; \quad 51.85 \% \pm 0.63)$ whereas Seeni banana showed the lowest (IC 50 : $54.65 \% \pm 0.11$ ). The highest ABTS+ radical scavenging activity was reported in lime peel (IC50: $51.56 \% \pm 0.35$ ) and the lowest was observed in Seeni variety (IC50: $67.14 \% \pm 1.38)$. The total TBARS content was low in lime peel extract the antioxidant activity was high (2.205 $\mu \mathrm{M} / \mathrm{g})$. However, in contract to the expectation, banana peel extracts $(100 \%)$ revealed no antimicrobial activity against $S$. aureus and $E$. coli. However, a considerable antimicrobial effect was observed only by the lime peel extracts. The absolute lime peel extracts $(300 \mu \mathrm{l})$ showed an inhibitory zone of $1.9 \pm 0.0 \mathrm{~cm}$ against E.coli and $1.8 \pm 0.1 \mathrm{~cm}$ against $S$. aureus. The results of this study will aid in utilizing the peel extracts of banana and lime in developing food products with antioxidant and antimicrobial properties

antioxidant and antimicrobial agents. Chemical and Pharmaceutical Research. 8(4), 46-55.

Acheampong, A., Borquaye, L. S., Acquaah, S. O., Osei-Owusu, J., and Tuani, G. K. (2015). Antimicrobial activities of some leaves and fruit peels hydrosols. International Journal of 
Chemical and Biomolecular Science. 1(3), 158162.

Ayala-Zavala, J., Vega-Vega, V., Rosas-Domínguez, C., Palafox-Carlos, H., Villa-Rodriguez, J. A., Siddiqui, M. W., and González-Aguilar, G. A. (2011). Agro-industrial potential of exoticfruit byproducts as a source of food additives. Food Research International. 44(7), 1866-1874.

Bankar A, Joshi B, Ravi KA, and Zinjarde S. (2010). Banana peel extract mediated synthesis of gold nanoparticles. Colloids and Surfaces B. Biointerfaces. 80, 45-50.

Bocco, A., Cuvelier, M. E., Richard, H., and Berset, C. (1998). Antioxidant activity and phenolic composition of citrus peel and seed extracts. Journal of Agricultural and Food Chemistry. 46(6), 2123-2129.

Chabuck, Z. A. G., Al-Charrakh, A. H., Hindi, N. K. K., and Hindi, S. K. K. (2013). Antimicrobial effect of aqueous banana peel extract, Iraq. Res. Gate. Pharm. Sci. 1, 73-5.

Chen, H., Song, F., Chen, W., and Chen, W. (2017). Inhibition of Corn Oil Peroxidation by Extracts from Defatted Seeds of Camellia oleifera Abel. Journal of Food Quality.2017.

Dosoky, N. S., and Setzer, W. N. (2018). Biological activities and safety of Citrus spp. essential oils. International journal of molecular sciences. 19(7),1907-1966.

Farasat, M., Khavari-Nejad, R. A., Nabavi, S. M. B., and Namjooyan, F. (2014). Antioxidant activity, total phenolics and flavonoid contents of some edible green seaweeds from northern coasts of the Persian Gulf. Iranian Journal of Pharmaceutical Research:IJPR. 13(1), 163-170.

Fatemeh, S. R., Saifullah, R., Abbas, F. M. A., and Azhar, M. E. (2012). Total phenolics, flavonoids and antioxidant activity of banana pulp and peel flours: influence of variety and stage of ripeness. International Food Research Journal. 19(3), 1041-1046.

Rebello, L. P. G., Ramos, A. M., Pertuzatti, P. B., Barcia, M. T., Castillo-Muñoz, N., and HermosínGutiérrez, I. (2014). Flour of banana (Musa AAA) peel as a source of antioxidant phenolic compounds. Food Research International. 55, 397-403.

González-Montelongo, R., Lobo, M. G., and González, M. (2010). Antioxidant activity in banana peel extracts: Testing extraction conditions and related bioactive compounds. Food Chemistry. 119(3), 1030-1039.
Gowe, C. (2015). Review on potential use of fruit and vegetables by-products as a valuable source of natural food additives. Food Science and Quality Management. 45, 47-61.

Kevers, C., Falkowski, M., Tabart, J., Defraigne, J. O., Dommes, J., and Pincemail, J. (2007). Evolution of antioxidant capacity during storage of selected fruits and vegetables. Journal of agricultural and food chemistry. 55(21), 85968603.

Loizzo, M. R., Tundis, R., Bonesi, M., Menichini, F., De Luca, D., Colica, C., and Menichini, F. (2012). Evaluation of Citrus aurantifolia peel and leaves extracts for their chemical composition, antioxidant and anti-cholinesterase activities. Journal of the Science of Food and Agriculture. 92(15), 2960-2967.

Lordan, S., Smyth, T. J., Soler-Vila, A., Stanton, C., and Ross, R. P. (2013). The $\alpha$-amylase and $\alpha$ glucosidase inhibitory effects of Irish seaweed extracts. Food Chemistry. 141(3), 2170-2176

Mahmud, S., Saleem, M., Siddique, S., Ahmed, R., Khanum, R., and Perveen, Z. (2009). Volatile components, antioxidant and antimicrobial activity of Citrus acida var. sour lime peel oil. Journal of Saudi Chemical Society. 13(2), 195198.

Mahmud, S., Saleem, M., Siddique, S., Ahmed, R., Khanum, R., and Perveen, Z. (2009). Volatile components, antioxidant and antimicrobial activity of Citrus acida var. sour lime peel oil. Journal of Saudi Chemical Society. 13(2), 195198.

Obinna N.C, Nwodo C.S, and Olayinka A.O, (2008). Evaluation of antibacterial activity of Pisidium guajava and Gongronema Latifolium, Journal of Medicinal Plants Research. 2(8), 189-192.

Rajurkar, N. S., and Hande, S. M. (2011). Estimation of phytochemical content and antioxidant activity of some selected traditional Indian medicinal plants. Indian Journal of Pharmaceutical Sciences. 73(2), 146-151.

Sekar, M., Fatihah, P. N., Safwan, N., Syahirah, Z., Krishnaswamy, N., Syafiq, M., and Izzaty, E. (2013). Comparative evaluation of antimicrobial properties of citrus varieties available in Malaysia market. 5(4).

Singanusong, R., Nipornram, S., Tochampa, W., and Rattanatraiwong, P. (2015). Low power ultrasound-assisted extraction of phenolic compounds from mandarin (Citrus reticulata Blanco cv. Sainampueng) and lime (Citrus aurantifolia) peels and the antioxidant. Food Analytical Methods. 8(5), 1112-1123. 
Stefanovic, O., and Comic, L. (2012). Synergistic antibacterial interaction between Melissa officinalis extracts an antibiotics, Journal of Applied Pharmaceutical Science. 2(1), 1-5.
Sumathy, N H, and Sumathy, JH. (2017). Antibacterial and Antifungal Activity of Musa Fruit Peels against Skin and Gastrointestinal Tract Diseases. Herbal Tech Industry. 2, 9-11. 